$\begin{array}{ll}\text { Article } & \text { European } \\ \text { Journal } O & \mathcal{O} \text { Industrial } \\ \text { Relations }\end{array}$

\title{
Workplace trade union engagement with European Works Councils and transnational agreements: The case of Volkswagen Europe
}

European Journal of Industrial Relations 2017, Vol. 23(4) 397-414

(C) The Author(s) 2017

Reprints and permissions: sagepub.co.uk/journalsPermissions.nav DOI: $10.1177 / 1721727 \times 17699444$ journals.sagepub.com/home/ejd

\section{Michael Whittall}

Friedrich-Alexander-Universität Erlangen-Nürnberg, Germany

Nottingham Trent University, England

\section{Miguel Martínez Lucio}

The University of Manchester, UK

\section{Stephen Mustchin}

The University of Manchester, UK

\section{Volker Telljohann}

Istituto Ricerche Economiche e Sociali (IRES) Emilia-Romagna, Italy

\section{Fernando Rocha Sánchez}

Fundación $I^{\circ}$ de Mayo, Spain

\begin{abstract}
This article examines two transnational agreements signed by the Volkswagen European and Global Works Councils, considering their interlinked implementation within subsidiaries in Britain, Italy, Spain and Germany. We demonstrate differing stances and some uncertainty towards principles of co-management, social dialogue and codetermination. These agreements have improved local industrial relations and strengthened cross-national interaction between employee representatives, despite significant differences in orientation regarding how unions should engage with management. However, the emerging international framework has not led
\end{abstract}

\section{Corresponding author:}

Michael Whittall, Institut für Soziologie, Friedrich-Alexander-Universität Erlangen-Nürnberg, Kochstraße 4, 91054 Erlangen, Nuremberg, Germany.

Email: michael.whittall@fau.de 
to a clear politics of incorporation, with local trade unions being well aware of the risks of comanagement and a more business-oriented relationship.

\section{Keywords}

Britain, Germany, Italy, Spain, transnational agreements, Volkswagen

\section{Introduction}

Volkswagen (VW) was a pioneer in the area of transnational employee representation, establishing in the 1990s one of the first European Works Councils (EWCs) in Germany and then a Global Works Council (GWC). Recently, these have negotiated innovative transnational company agreements (TCAs) relating to labour relations and to temporary agency work (TAW). The first agreement has set substantive frameworks for participation rights, and the second, reference points regarding the proportions and retention of temporary agency workers.

In this article, we examine the negotiation and implementation of these agreements, and how they were evaluated by workplace representatives in Britain (Bentley), Germany (VW/Audi), Italy (Lamborghini) and Spain (Navarra). During our interviews, delegates generally lauded the merits of the European and Global Works Councils (E\&GWCs) and the TCAs. Such positive assessments, though, obscure a complex set of interrelationships between E\&GWC delegates and national employee representatives in the development of TCAs, and in accommodating the distinctive nature of national industrial relations practices.

The research formed part of a wider comparative study conducted in 2014-2015, led by the Confederazione generale italiana del lavoro (CGIL), with academic and union partners from Spain, the United Kingdom, Germany, France, Poland and Bulgaria (Leonardi, 2015). It explored the local implementation of TCAs, including European and international framework agreements (European Framework Agreements (EFAs) and International Framework Agreements (IFAs)), particularly in the financial services and metal-working sectors. Research was undertaken in seven multinational companies (MNCs), with over 50 interviews with union, works council and EWC representatives, together with documentary analysis and participation in three international practitioner and academic workshops. VW was one of these cases, and the authors conducted the four national level studies in its subsidiaries, before drawing up the final report that provides the empirical basis for this article. These data were analysed inductively in light of key debates in the literature on EWCs, TCAs and changing national systems of industrial relations.

Sensitivities were evident regarding the perceived hegemony of German unions and works councils in the company. Employee representatives, especially from outside Germany, welcomed having their influence strengthened but were wary that empowerment could entail certain risks, in particular fears, that close association with management could threaten their much guarded independence.

We suggest that the two TCAs symbolize the maturity achieved by the E\&GWCs, which allows delegates time and space to feed transnational discussions into the national 
discourse and ensure that any agreement is compatible, first with the local setting and second with the need for legitimacy that has to underpin all TCAs. Maturity alone, though, does not ensure the successful development and implementation of TCAs, and certain prerequisites must prevail to help encourage constructive relations between the numerous national affiliates. First, there is a need for strong and well-resourced representative structures at national and transnational levels. Second, there must be a universal commitment to trade union representation which transcends national idiosyncrasies and lays the foundation for high trust between transnational delegates, especially between German representatives with direct access to central management and their counterparts in non-German subsidiaries. Various non-German respondents were fully aware that there existed different levels of trust within their local systems and that the relationship with local management had limitations, thus, reproducing some perceived notion of German 'co-management' was questionable.

In order to examine what TCAs have achieved and whether they establish a new platform of rights, we begin by looking closely at TCAs, in general: their prevalence, the issues they address and their overall character. Next, we turn to VW and the character of employee representation within the company transnationally; we argue that these relations are more nuanced than normally suggested in the literature. We analyse the negotiation of the two TCAs and reflect on their impact and the value of such agreements for local actors within the four countries.

\section{The emergence of TCAs}

TCAs have been growing in importance since the early 2000s (Helfen and Fichter, 2013; McCallum, 2013; Telljohann et al., 2009), representing a new method of regulation on which employee representatives can call when MNCs are committed to a strategy of centralization (Leonardi, 2015; Telljohann et al., 2009). Transnational employee representation bodies that engage with TCAs have faced criticism on grounds of weaknesses in the regulation underpinning EWCs, and their often limited outcomes (Streeck, 1997; Waddington, 2011) and tensions that may exist between representatives from different national industrial relations systems and cultures (Kotthoff and Whittall, 2014; Pulignano, 2005; Royle et al., 2016). Early TCAs often consisted mainly of generic commitments to core labour standards, but more recently some have moved beyond this, with global union federation (GUF) campaigns on precarious work leading to commitments to restrict the use of TAW (Cotton, 2015). This has been augmented by German union's efforts to strengthen organization among peripheral workers as a means of containing employer segmentation strategies (Benassi, 2015). This increased concern with regulating the use of agency workers in MNCs is a key concern of this article.

The identity of MNCs is in constant flux, with an ever increasing number of mergers and acquisitions, making it difficult to determine the number of TCAs. According to the most recent figures (Rehfeldt, 2015: 27), the total currently stands at around 267. Of these, 140 are IFAs and 127 are EFAs. While IFAs mainly go beyond the regional scope and are co-signed by GUFs, EFAs are restricted to the European sphere and predominantly initiated and signed by EWCs (Carley and Hall, 2006). 
Another distinction between these two forms of agreement concerns content. EFAs 'deal with a greater variety of issues, mainly restructuring, occupational health and safety, social dialogue procedures, human resource management, corporate social responsibility', than IFAs (Rehfeldt, 2015: 29). Research generally suggests that TCAs represent a novel response to employers' search for greater flexibility and control over the labour process; however, the pace of new agreements has declined in recent years, possibly the result of a re-nationalization of industrial relations (Rehfeldt, 2015) in the wake of the economic crisis or a move towards informalization (Rüb et al., 2013).

\section{VW: a global giant engaged in social dialogue}

In 2015, VW had 119 production sites in 31 countries, 20 of these in Europe (Whittall et al., 2015). The company is not only a standard bearer for the German industry but equally a symbol of German corporatism. Organized labour has played a key role in the running of the company, which was state owned until 1960. Even in a country where employee interests are underpinned by legislation, the role of works councils and the trade union $I G$ Metall remains unique.

The company's commitment to social partnership is not restricted to Germany: in the 1990s, it provided employees in Europe and beyond with a voice through the E\&GWCs. This formalized transnational linkages between German VW workers and labour in its global subsidiaries, a history of internationalism that is a source of pride but which created tensions at certain junctures because of competition, whipsawing and diverse systems of representation within the firm (Bolsmann, 2007, 2010). The EWC was set up in 1992, 2 years before the EWC Directive was adopted. The GWC was established 7 years later (Rüb, 2002). Currently, the EWC and GWC host 70 and 100 delegates, respectively.

From the firm's perspective, a key motivation for the establishment of these institutions and agreements was to coordinate and manage often conflictual processes of competition and investment allocation within its global operations, as well as to maintain strong relationships with IG Metall at headquarters level. These relationships had been criticized following the corruption scandal of 2005 involving the then EWC chair (Greer and Hauptmeier, 2015). This placed pressure on VW to reform industrial relations, corporate governance and work organization. It was also influenced by wider criticisms of stakeholder capitalism (Clark, 2006), even though the works council and union in Germany engaged in concession bargaining throughout the 1990s (Edwards, 2004). Similar criticisms followed the recent scandal regarding manipulated emissions tests (Elson et al., 2015), while these issues unfolded after our research was concluded, they place evident pressure on the firm, employment levels and institutional configurations: they also suggest that our findings about the pragmatic approach to trade union participation in decision-making in the non-German cases are well grounded.

\section{The emergence of TCAs at VW: labour relations and TAW}

The TCAs within the VW Group can be traced back to the signing of a declaration on Social Rights and Industrial Relationships in 2002. Although six TCAs have been signed 
Table I. Volkswagen transnational declarations and agreements.

\begin{tabular}{|c|c|c|c|}
\hline Charter & Year & Signatory & Aims \\
\hline Social charter & 2002 & $\begin{array}{l}\text { Volkswagen AG, GWC, } \\
\text { IMF }\end{array}$ & $\begin{array}{l}\text { Application of key ILO conventions, } \\
\text { also in suppliers. }\end{array}$ \\
\hline Health and safety & 2004 & $\begin{array}{l}\text { Volkswagen AG, GWC, } \\
\text { IMF }\end{array}$ & Prevent health risks \\
\hline $\begin{array}{l}\text { Sustainability and } \\
\text { supplier relations }\end{array}$ & 2006 & & $\begin{array}{l}\text { Prescribe corporate standards for } \\
\text { business partners }\end{array}$ \\
\hline Labour relations & 2009 & $\begin{array}{l}\text { Volkswagen AG, GWC, } \\
\text { EWC, IMF }\end{array}$ & $\begin{array}{l}\text { Commitment to establishing } \\
\text { employee codetermination } \\
\text { structures. }\end{array}$ \\
\hline $\begin{array}{l}\text { Review of social } \\
\text { charter }\end{array}$ & 2012 & & $\begin{array}{l}\text { More specific regulation with regard } \\
\text { to 'compensation' }\end{array}$ \\
\hline TAW & 2012 & $\begin{array}{l}\text { Volkswagen AG, GWC, } \\
\text { EWC, IMF, IndustriAll }\end{array}$ & $\begin{array}{l}\text { Commitment to offering salaried } \\
\text { and agency workers the same rights }\end{array}$ \\
\hline $\begin{array}{l}\text { Education and } \\
\text { training }\end{array}$ & 2015 & $\begin{array}{l}\text { Volkswagen AG, GWC, } \\
\text { EWC, IMF }\end{array}$ & $\begin{array}{l}\text { Commitment to securing adequate } \\
\text { conditions for apprentices }\end{array}$ \\
\hline
\end{tabular}

in total (see Table 1), the 2009 and 2012 Charters dealing with Labour Relations and TAW are particularly pioneering.

Respondents regard the 2009 and 2012 Charters, endorsed by the VW board, the E\&GWCs and GUFs (International Metalworkers Federation, IMF, later IndustriALL), as ground-breaking agreements. They highlighted how the VW business strategy, specifically a managerial emphasis on measures to improve efficiency and productivity globally, necessitated not only a transnational employee response but also empowerment of employees at a national level. German works councillors said,

$\mathrm{OK}$, in response to the VW strategy, a strategy which is being implemented worldwide, we have to make sure that our colleagues are involved in such a process. Technically speaking, they [non-German employee representatives] require codetermination rights like we have in Germany.

A number of factors led the German joint works council to develop and promote the 2009 and 2012 Charters. There was awareness that 'sites are compared' (works councillor), and that sites are in competition with each other, and for this 'reason we [European and Global works councils] are attempting to influence these processes' (works councillor).

\section{The Labour Relations Charter}

The Charter of Labour Relations predated the Charter of Temporary Work by 3 years, as it was acknowledged that the latter TCA would be of little value to employees not in possession of the necessary institutional framework featured in the former agreement. The 
Preamble to the Labour Relations Charter clearly indicates that it is designed to promote workplace democracy:

With this Charter, the parties thereto establish the in-house participation rights of democratically elected employee representatives for the countries and regions represented on the European Group Works Council and the Group Global Works Council. Thus, this Charter constitutes a supplementation to existing agreements and declarations.

Since the 1990s, German trade unionists have been aware that globalization poses a threat to their inclusive system of industrial relations. Countries without strong trade unions and works councils are portrayed, certainly by management, as having a competitive advantage. Transferring German 'good practice' represents an opportunity to neutralize such a threat. Consequently, although German E\&GWC delegates took the lead in promoting the Charter, British, Italian and Spanish delegates have seen their status in their subsidiaries improve.

Though the Charter respects existing national industrial relations arrangements, an example of its flexibility, it is designed to put in place a system of industrial relations where this does not exist and to complement current arrangements. For example, in countries where a single channel of representation exists, usually in the form of a trade union, it offers actors the option of a works council with codetermination rights. Thus, the choice of participation rights - information, consultation and codetermination options set down in the Charter - is left to site actors to determine.

\section{The TAW Charter}

The Labour Relations Charter served as a platform for employees to implement more specific agreements, such as that on TAW in 2012, which has three specific aims. First, it aims to put a 5-percent cap on the number of agency workers employed. Second, it seeks to harmonize employment conditions between temporary and non-temporary workers including equal pay. Third, it aims to limit the period for which temporary workers can be employed while also offering agency workers the possibility of a permanent contract within the VW Group after this period. The agreement is notably flexible:

Should the figure exceed 5 percent per plant the company and workers representatives pledge to begin discussion in the context of the consultation mechanism, which is defined in the Charter on Labour Relations, whether a reduction in the level of temporary external employees is necessary and to bring about an amicable solution.

Such flexibility can also be observed in respect of the length of time an individual can be employed as a temporary agency worker. Although the agreement stipulates that the period should not exceed 36 months, again it does not exclude local agreements setting a lower cut-off point

In sum, the VW E\&GWCs have collectively acknowledged the importance of developing TCAs as a means of influencing the company's business strategy at a transnational level, including attempts to reduce the capacity of sites to compete on the basis of flexibility premised on the use of TAW. 


\section{The negotiation of transnational agreements and the question of ownership}

It might be thought that the negotiation of the two TCAs, in which the German works councils took the lead, was intended to protect German jobs. However, this does not appear to have undermined support for them on the part of non-German actors. Italian, Spanish and United Kingdom respondents acknowledged that a motivating factor for 'all' employee representatives was to protect jobs, and they welcomed the German initiative. They believed that TCAs could advance their own cause at home while promoting transnational employee solidarity. For example, British E\&GWC delegates view TCAs very much as part and parcel of a general internationalization of trade unionism and also offering trade unions in Bentley access to information pertaining to VW corporate strategy as well as the capacity to influence managerial decisions.

There was general acknowledgement that a strategy designed to raise labour standards had to be initiated and coordinated by German representatives. The access to the management board enjoyed by the well-resourced joint and company works councils, underpinned by strong German codetermination rights, made it inevitable that they played the leading role in negotiations. The challenge here involves the fine line between taking the lead while ensuring the international character of any eventual TCA, thus avoiding German domination of employment relations processes. Existing EWC research confirms that the dominance of the 'host country' poses a threat to transnational employee solidarity (Kotthoff and Whittall, 2014; Pulignano, 2005; Royle et al., 2016). Interviews with delegates from the E\&GWCs demonstrated awareness of this dilemma, given many years of working together. Hence, they developed a strategy that would neutralize any impression that the TCAs were a German appendage to be transferred to non-German industrial relations systems.

Ultimately, this involves managing diversity among the employee side, a diversity embedded in the differing industrial relations practices of E\&GWC delegates. This challenge became most obvious during discussions surrounding the Charter for Labour Relations. For example, non-German delegates raised real concerns that the Charter was ultimately an attempt to export the dual system of German industrial relations throughout the company. To alleviate such impressions, there was a commitment on the part of all E\&GWC delegates towards intensive and constant negotiations within VW. As a German joint works council representative explained, this process included developing discussion papers that were presented to the E\&GWCs:

We said we would develop a proposal. We took this to our internal committees where it was then discussed. I can remember in the case of the Labour Relations Charter that a Polish delegate said 'could you not write down in the Charter that the German Works Constitution Act is applicable to Poland?'

According to respondents from Italy, Spain and the United Kingdom, such an approach had the desired effect. A Spanish delegate noted, 'this dialogue and mutual trust encourage participation of unions of the affiliated centres, and favours the improvement of the texts agreed in the European and World committee'. 
Such discussions allowed delegates to bring specific concerns to the negotiation table. For example, the international agreements were used by British trade unionists to counter the use of TAW and subcontractors threatening to undermine worker standards.

We've used that here. And I don't mean just parts suppliers, I mean agency labour and things like that. For instance, [one supplier] doesn't recognize trade unions in the UK ... I've used our social charter ... to put pressure on them to say 'you will let your members speak to the union'. The company has agreed that our shop stewards can represent our people, who they work with anyway sometimes because they work on the track next to them ... So that's come as a direct consequence of the social charter.

Another key aspect designed to highlight the international as against the German character of the TCAs concerns the involvement of the GUFs, in this case the IMF which is now part of IndustriALL. In addition, German works council members often called on the services of $I G$ Metall when required, especially when this involved challenging the notion sometimes prevalent outside Germany that the works council was nothing more than an extended arm of the personnel department.

In sum, because of their superior resources and access to the board, German employee representatives inevitably lead the negotiations with management over the Charters. Nevertheless, experience garnered from their years of E\&GWC work highlighted the delicate nature of such a process, specifically the need to involve non-German employee representatives in drawing up and developing the TCAs. A considerable amount of effort had been invested to ensure that a common position prevails on the employee side. However, the real litmus test concerns the impact and value of such agreements at the national level.

\section{The implementation and value of TCAs for British, German, Italian and Spanish sites}

\section{Germany: VW and Audi}

Although Wolfsburg remains the heart of VW, with over 53,000 employees, there are a total of 26 production sites across Germany, employing just under 166,000 workers across VW, Porsche Group, Audi and MAN. These acquisitions and expansion have helped to consolidate vehicle production and to strengthen employee representation in Germany.

The implementation process. In Germany, the institutional framework, in particular the existence of joint and company works councils, ensured that these two institutions played a pivotal role in the implementation and monitoring of the Charters. Once they were signed, both bodies had the task of considering what specific aspects of the agreements would benefit German employees. It is important to recall, though, that the agreements provide a high degree of flexibility. They are frameworks, allowing representatives to select facets from the Charters and policy papers which meet their specific needs. In 
addition, considerable effort was made to encourage dialogue with local representatives over the implementation process. As was the case at the transnational level, the success of TCAs involved a high degree of decentralization in their implementation. A German works councillor commented on the relationship between Wolfsburg and smaller sites:

The fact that one jointly enters into discussions, answers questions, also critical questions, and attempts to explain that these rules are part of a number of options that employee representatives can take advantage of, options that surpass what is legally allowed ... When this is jointly achieved then there is a good chance to attain a high acceptance rate. You then experience at the local level how employee representatives are really keen to implement such Charters.

The framework character of the Charters and the discussions surrounding the process of implementation led to some differences in outcomes between sites represented on the company works council. This is most obvious in relation to the TAW Charter. For example, the Audi works council negotiated a number of issues, which surpassed the minimum standards set down in the Charter: a 2-percent quota for temporary agency workers and a 24-month limit on their employment. The flexibility built into the Charters, deemed necessary to take account of national idiosyncrasies, proved invaluable when implementing such agreements. Not only does it recognize that the company works council is made up of various subsidiaries, including Audi, Porsche and MAN, each facing different product market challenges, it also respects the decentralized nature of German industrial relations.

The value ofTCAs. At first sight, the Charters might appear to be of little value to German employees. Armed with a battery of codetermination rights both at plant and company levels as well as having IG Metall, the world's largest and arguably most powerful union at their disposal, they might see TCAs as necessary only for the 'rest' of the world. However, the proliferation of agency work has dominated German labour relations in the last decade. The TAW Charter represents a major breakthrough, addressing two issues, equal pay and maximum duration, that $I G$ Metall has long deemed to be essential in ensuring the equitable use of such employment methods. For example, as a consequence of the 36-month limit and the commitment to employ individuals on permanent contracts once this threshold is reached, around 5000 agency workers transferred to VW in 2013.

In addition, an important quality of the TAW Charter concerns its codetermination character. A works councillor indicated that 'generally we have the codetermination rights in the case of individual employees and recruitment of temporary workers ... Therefore, when the [5 percent] quota is to be exceeded, they [management] need to get our approval'. Even though VW is often thought to surpass the high standards set down in German labour law, respondents were eager to point out the importance of the Labour Relations Charter in their own work. They insisted that conflict was as much a part of VW labour relations culture as social partnership and wished to dispel any myths which assumed that industrial relations were ideal. For example, VW Germany consists of 100 enterprises, many of them small- to medium-sized firms in which the codetermination culture is not as developed as in Wolfsburg, Ingolstadt (Audi) and Stuttgart-Zuffenhausen (Porsche). One works councillor stressed that 
it is not the case that the Works Constitution Act is practised in our 100 German enterprises as it is at Volkswagen or Audi ... This is because we naturally have small enterprises where the works councils have a much more difficult time.

The Charter on Labour Relations also benefited some members of the company works council. Audi, for instance, was able to use it to implement the 'plant-level symposium' (Standortsymposium) structure long in place in Wolfsburg. This provides annual meetings between senior management, employee representatives and the workforce to discuss questions directly related to their plant:

We have the opportunity here to say 'here we have a problem and we urgently need to find a solution'. We naturally inform our plant management in advance. We tell them that we will raise an issue. But we have the chance really to address problems: to discuss problems directly with the board and with our plant management.

Finally, from a German perspective the Charter on Labour Relations has a symbolic importance which should not be underestimated. Respondents were keen to highlight that irrespective of the legislation underpinning German industrial relations, the Charter demonstrates management's commitment to codetermination at VW. In a period when employers' associations sporadically question the value of codetermination legislation, an agreement which confirms the company's support of workers' rights represents a positive signal.

\section{Italy: Lamborghini}

Acquired by VW in 1998 and under the control of VW's subsidiary Audi, Lamborghini employs 1391 employees with a strong tradition of company-level collective bargaining. Management favoured cooperative relations with employee representatives, tendencies that predated the takeover (Whittall et al., 2015). Within the company as a whole, but specifically in production, unions were quite well represented, with a membership density of approximately 40 percent.

The implementation process. In 2010, a year after the Labour Relations Charter was signed, Lamborghini and the VW sales organization in Verona were the first Italian locations to start its implementation. Employee representatives were initially mistrustful of the notion of shared responsibility, which did not sit well with the more conflictual tradition of Italian industrial relations. Trade unions were concerned that the Charter represented the export of the German codetermination model to Italy and threatened the Italian single-tier system of interest representation.

However, at the beginning of 2011, trade unions and employee representatives negotiated a Declaration of Intent confirming their interest in implementing the Charter. Lamborghini's interpretation of the Charter committed the company to improving the existing model of industrial relations while maintaining national collective bargaining practices, with codetermination to be achieved in the context of company-level collective agreements. During negotiations, German employee representatives were invaluable 
in demonstrating that codetermination does not exclude conflict, and that it represents an additional tool for employees to further their interests.

A year after the Declaration of Intent, a company collective agreement was negotiated, extending participation rights to the areas of work organization and working methods, job classification and training, ergonomics and health and safety and performance-related bonuses. In addition, to facilitate work in these areas, so-called bilateral technical commissions were set-up. This approach involved a clear division of labour between the commissions and the company-level structures of interest representation, and thus between participation and company-level collective bargaining.

As in Germany, specifically at Audi, the Lamborghini arrangement sought to control when, how long and under what conditions temporary agency workers can be used: the maximum period they can be employed cannot exceed 18 months, Lamborghini is obliged to recruit permanent workers from the pool of current or former temporary workers and unions now represent the temporary workers, pressurizing management to move 300 temporary staff onto permanent contracts.

The added value ofTCAs. The Lamborghini case demonstrates that TCAs can have a positive impact on national industrial relations practices. For example, although companylevel agreements provided the Rappresentanza sindacale unitaria (RSU) with participatory rights, their actual worth was undermined by the fact that local management did not really support the implementation of these rights. In contrast, though, TCAs signed by central management and championed by the E\&GWCs ensured that the RSU possessed a standing that the Italian management could no longer ignore. The Labour Relations Charter not only provides rights that surpass national standards regarding information, consultation and codetermination, but moreover raises the status of the RSU. Discussing the situation at Lamborghini an employee representative noted,

For us the TCAs in a certain sense represent a toolbox which allows us to enlarge our rights at company level. At the same time the TCAs are like an umbrella. They protect our achievements as they have been signed by central management. Thus, for the local management it becomes more difficult to question these achievements.

Additionally, agreements such as the TAW Charter were a useful defence against social dumping risks related to outsourcing and a means of preventing the disintegration of industrial relations in the sector (as seen within the more conflictual climate in FiatChrysler) by combining local actions with transnational instruments, creating strengthened employee representation structures and a more cooperative approach to industrial relations.

\section{The United Kingdom: Bentley}

VW acquired Bentley in 1998, leading to major increases in production through the exploitation of new markets, including the Middle East and China. Bentley is renowned for its robust industrial relations practices, drawing on strong workplace organization deriving from engineering trade union traditions. Union density is 90 percent, mostly in 
the lead union Unite, well above the average for private sector manufacturing in the United Kingdom.

The implementation process. The implementation of both TCAs has to be seen in connection with the general process of Europeanization within Bentley. As in the case of Lamborghini, industrial relations in the past had been relatively conflictual and geared towards single-channel union representation. The support of Bentley union and employee representatives for the Charters reflects an acceptance that social dialogue has a role to play. Their relatively smooth implementation was made possible by the benefits deriving from improved access to information, increased legitimacy gained by UK unions from working with the EWC and the emergence of a new, more inclusive, partnership-oriented approach to union-management relations.

This new industrial relations environment allowed the protagonists at Bentley to implement key aspects of the two Charters in 2010 and 2013, respectively. In the case of the TAW Charter, the eventual agreement used the TCA as a template, specifically improving the terms and conditions of temporary workers, limiting their proportions to 5 percent and supporting union access to and membership among agency workers. Bentley led the way within the wider VW Group in implementing this TCA: in the words of an EWC representative, 'we've got a Bentley version of this thing, and we signed it. We're the first to do it, to conclude. This is because everybody else has got bogged down with the numbers'.

As in Germany and Italy, the implementation process was greatly assisted by the inherent flexibility and contextual sensitivity of the TCAs in framing agreements and respecting local variations. In sum, the implementation of most aspects of the agreements had been relatively unproblematic in Bentley, despite some questions, which reflected a highly strategic and organized union branch with the ability to lead and engage on a range of issues.

The added value of TCAs. TCAs framed the development of social dialogue in the UK case, and the TAW Charter helped Unite to organize among agency workers and regulate their use. The status of the E\&GWCs as not only role models but also allies was highly significant, involving notable cultural change, greater transparency and management accountability. The newly won status of Bentley employee representatives resulting from their E\&GWC membership, and less formalized benefits of such engagement, were evident:

Nothing beats close links, when you can have a friendship and you get on with people, it's not just work-related, you can discuss things more privately and personally; whereas I would tend to say that it wouldn't happen on the [management] side ... The communication is sometimes overkill, and not the correct type of information; but nothing gets brought from Europe from the company, it's all from the EWC representative.

This shows how the international activity of trade unions was premised on both formal social dialogue and agreements, and less formal networks, structures and activism. These were used in negotiations where VW planned to produce a new model in an 
Eastern European plant; the transnational networks and insistence on the British identity of Bentley maintained production in the United Kingdom, with subsequent increases in employment, demonstrating tangible benefits to the British workforce from international engagement.

Some tensions were evident within such processes of Europeanization. As at Lamborghini, enhancing the local impact of such processes is contingent on the resources and investment of the trade union locally. There were concerns that British representatives were not always strategically integrated, resourced or supported locally as they were seen to be in Germany, but these criticisms were tempered by awareness that such relationships and the nature of the German codetermination system could bring risks to the level of trust and independence of the local union, given the national system of labour relations and a culture which does not support unions in becoming more involved (Martínez Lucio and Stuart, 2004).

\section{Spain: VW Navarra}

VW Navarra SA is a Spanish production plant within the VW Group and currently the main production site for the new Polo. Incorporated into the company at the end of 1993, the plant opened in January 1994. In December 1997, VW Navarra was transferred to SEAT SA, making SEAT its sole shareholder. This plant is more oriented to lower cost mass production than the more specialized subsidiaries in the United Kingdom and Italy, which is a significant difference.

The plant employs around 4300 workers, with 75 percent permanent staff and 25 percent temporary agency workers. Union density is around 80 percent, and participation in workplace union elections is around 90 percent. In accordance with the 1980 Estatuto de los trabajadores (Workers' Statute), it possesses a works committee composed of 29 union representatives. The largest groups are 11 members from the Unión General de Trabajadores (UGT) and 7 from the Comisiones Obreras (CCOO). Members of both unions sit on the E\&GWC. In the last decade, industrial relations within the plant had changed quite radically; interaction between social partners had become more open and less marked by industrial action.

The implementation process. Of all the four cases, the Navarra plant had struggled most to implement the Charters. To date, industrial relations actors have made limited progress in implementing the Labour Relations Charter, and a site-specific participation agreement had still to be formalized at the time of writing. Both employers and employee representatives attributed the delay to the principle of the 'right to codetermination' established in the Charter. As in Italy and the United Kingdom, the unions appeared to be circumspect about the principle of codetermination.

However, despite the lack of an agreement, both sides sought a way out of the deadlock. Without a formal agreement, they applied the spirit of the Charter, specifically the notions of participation, to implement certain aspects within local collective agreements. This unique solution sought to play down the codetermination aspect of the TCA, falling back on information and consultation rights to reach agreements: 
We are developing in practical terms a dynamic of industrial relations very similar to codetermination, although without this label, based on two principles: first, give detailed information on all labour issues to the works council; and second, promoting consensus and agreement with the most representative trade unions. In this regard, we don't impose and will not impose unilateral decisions on working conditions, in spite of the fact that we are legally entitled to.

Ultimately, addressing the issues laid down in the Charter of Labour Relations in a way that was acceptable to Spanish employee representatives involved a collective bargaining approach controlled by the two main unions. This allowed for the gradual implementation of certain codetermination factors laid down in the TCA, but the adoption of the German model remains questionable without broader state support and clearer commitments to enhanced union roles.

The value of TCAs. The Charter on Labour Relations has had three main effects in the Navarra plant. First, informal relations between management and employee representatives from the UGT and CCOO were strengthened, leading to improved information and consultation rights. Second, this improved industrial relations climate enabled the social partners to conclude agreements on the voluntary reduction of working hours, exemption from night shifts, improvement in the conditions for purchasing used cars by employees, professional accreditation, the aggregation of reduced workdays and a voluntary redundancy scheme.

The third outcome was the support Spanish employee representatives gained from the EWC when negotiating at a local level. 'Nowadays there is a direct relationship through email and phone with the leadership of the EWC. Indeed, in difficult negotiations over collective agreements, the EWC helped to unblock the bargaining process'.

In sum, the social partners generally view the TCAs positively. The Labour Relations Charter was seen to have encouraged and consolidated a more participative industrial relations culture. Questions remain, however, regarding the sustainability of such an approach, especially in the current period of economic crisis that the conservative government has exploited to undermine employee rights. So far, VW management has refused to apply Spanish neoliberal reforms to undermine local labour and employment relations, but should management change their position the real value of the E\&GWC is likely to be tested.

\section{Conclusion: the virtues of reflection and flexibility}

The VW case raises interesting questions about the nature of relations between employee representatives at transnational level, particularly the contribution of TCAs to developing solidarity among E\&GWC delegates. There are clearly positive signs in how they begin to frame activities in national contexts and how they become points of reference between national trade unions, especially when contextualized through E\&GWCs. Furthermore, there were signs of increasing maturity and subtlety in the way international relations with management were emerging, the use of international coordination and links to the German headquarters. 
Such institutional features as codetermination are not shared by trade unionists in some national systems of employment relations. The Italian, Spanish and British interviewees welcomed having their influence and presence extended, with management informing them as soon as possible about developments. Nevertheless, it was clear that for all the positive features of the TCAs, they were unwilling to become 'too close' to management, and were wary of joint working and collaboration that undermined their critical distance from the employer. In effect, these three cases showed a degree of realism and reflection based on sober assessments of the possibilities and risks of these new institutional developments. The 2005 corruption scandal and the more recent emissions scandal make the trade unions aware of the risks of co-management when decisionmaking is more oblique than may first appear. It suggests a certain degree of maturity, a recognition that transnational relations between labour representatives require a greater amount of subtlety in the ways that any agreements are interpreted and implemented. Ultimately, this involves investing considerable thought into how the TCA agreements can be made transparent and empowering, and how E\&GWC delegates (especially those outside Germany) can not only be informed of developments but can also actually influence them. Although respondents suggest this deliberative aspect of transnational relationships can be time-consuming and problematic, inability to address these issues would doom any such agreements to failure.

Given their strategic presence and substantive resources, the German trade union apparatus often led and oversaw negotiations, but this did not appear to create serious internal problems within the EWC and parallel structures. This may be in part because the German unions are more committed to social dialogue and views of trade union influence that are largely shared by others in networks of organized labour within VW. It also appears that many years of working alongside other trade unions and national bodies have sensitized representatives to the need for consensus. How this is sustained is another matter, yet negotiations have become more systematic and linked to the development of the E\&GWCs. In this respect, the TCA represents the outcome of established hierarchical processes and also changes in reflective capacities in relation to the need to negotiate and build alliances across organized labour internationally.

The TCAs and related agreements have set substantive frameworks for core labour rights, which senior VW management at this stage do not seem to question (although the absence of clear trade union recognition at VW Tennessee raises problems for the future). More importantly, TCAs promote negotiations both locally and nationally that share concrete reference points on questions, such as the proportion of temporary workers that can be employed. Whether this is systematically adhered to is another matter, and pessimists would regard TCAs as primarily symbolic and with limited practical impact. However, these new frameworks create a series of important dialogues that link together key issues regarding the peripheral workforce and those excluded from the longer term benefits of employment at VW. The TCA in this respect has a synchronizing effect in discursive terms at least. What is more, at times of national conflict these agreements became important and were referenced by the trade unions to ensure modifications in management behaviour. Hence, while flexibility is built into the TCAs, this partly reflects actors' perceived role in prompting discussion and opening up spaces around new employment issues. 
For the UK representatives, TCAs were considered one positive aspect of an overall formal and informal process of international labour coordination. The Spanish representatives developed a more focused scrutiny, partly because of the nature of its own agreement-making process and the longer history of VW locally. In Italy, the labour standards introduced through TCAs are now used as benchmarks at the sectoral level, as well as along the value chain. The different national approaches to TCAs are to be expected, given the distinctive traditions of regulation in each context, particularly the different ways in which informal relations are constructed. More generally, however, there was growing awareness that such agreements framed discussions about how VW should behave in other parts of the world. The TCAs were evoked in discussions of the problems of unionizing in the Tennessee plant, as were various other protocols by European trade unionists involved in assisting their American counterparts.

Another important contribution of the agreements negotiated by the E\&GWCs concerns the resourcing of trade unions and worker representatives: an issue that may become more important as the representatives' international work extends further and agreements have to be monitored. The training of management was also considered important in this respect, as awareness of agreements needed to be extended not only among both national and local management but also within national industrial relations structures.

To conclude, the E\&GWCs, TCAs and transnational activity can have a significant impact on managerial decisions. The existence of such transnational bodies and agreements has brought benefits to employee representatives in all four countries studied, to different degrees, because of the ongoing depth of relations and cross-referencing. In a curious way, while the flexibility in the agreements and their implementation might be considered a weakness, they were actually strengths because they were deliberately articulated and coordinated. The representatives were cautious of the costs and risks of engagement, and undertook considerable work in negotiating among themselves and not just with management. The politics of such developments require an understanding of the complexity of relationships and debates within the labour movement. The debate on EWCs oscillates between positive and negative views, but the findings show that the trade unionists involved were well aware of the problems and challenges brought about by such a new framework of engagement.

\section{Declaration of Conflicting Interests}

The author(s) declared no potential conflicts of interest with respect to the research, authorship, and/or publication of this article.

\section{Funding}

The author(s) disclosed receipt of the following financial support for the research, authorship, and/ or publication of this article: The research was part of a European project "EURACTA 2 Transnational Company Agreements" and was Funded by the EU. Agreement number VS/2013/0350.

\section{References}

Benassi C (2015) From concession bargaining to broad workplace solidarity: The IG Metall response to agency work. In: Drahokoupil J (ed.) The Outsourcing Challenge: Organizing Workers across Fragmented Production Networks. Brussels: ETUI, pp. 237-254. 
Bolsmann C (2007) Trade-union internationalism and solidarity in the struggle against apartheid: A Case Study of Volkswagen. Historical Studies in Industrial Relations 23-24: $103-124$.

Bolsmann C (2010) Contesting labor internationalism: The 'old' trapped in the 'new' in Volkswagen's South African plant. Labor Studies Journal 35(4): 520-539.

Carley M and Hall M (2006) European Works Councils and Transnational Restructuring. Dublin: European Foundation.

Clark I (2006) Another third way? VW and the trials of stakeholder capitalism. Industrial Relations Journal 37(6): 593-606.

Cotton E (2015) Transnational regulation of temporary agency work: Compromised partnership between Private Employment Agencies and Global Union Federations. Work, Employment and Society 29(1): 137-153.

Edwards T (2004) Corporate governance, industrial relations and trends in company-level restructuring in Europe: Convergence towards the Anglo-American model? Industrial Relations Journal 35(6): 518-535.

Elson C, Ferrere C and Goossen N (2015) The bug at Volkswagen: Lessons in co-determination, ownership, and board structure. Journal of Applied Corporate Finance 27(4): 27-43.

Greer I and Hauptmeier M (2015) Management whipsawing: The staging of labor competition under globalization. ILR Review 69(1): 29-52.

Helfen M and Fichter M (2013) Building transnational union networks across global production networks: Conceptualising a new arena of labour-management relations. British Journal of Industrial Relations 51(3): 553-576.

Kotthoff H and Whittall M (2014) Paths to Transnational Solidarity Identity-Building Processes in European Works Councils. Brussels: Peter Lang.

Leonardi S (ed.) (2015) The Transnational Company Agreements: Experiences and Prospects. Rome: Associazione Bruno Trentin. Available at: http://www.fondazionedivittorio.it/it/euracta-2

McCallum J (2013) Global Unions, Local Power: The New Spirit of Transnational Labor Organizing. Ithaca, NY: Cornell University Press.

Martínez Lucio M and Stuart M (2004) Swimming against the tide: Social partnership, mutual gains and the revival of 'tired' HRM. International Journal of Human Resource Management 15(2): 410-424.

Pulignano V (2005) EWCs' cross-national employee representative coordination: A case of trade union cooperation? Economic and Industrial Democracy 26(3): 383-412.

Rehfeldt U (2015) Transnational company agreements: A map. In: Leonardi S (ed.) Transnational Company Agreements: Experience and Prospects. Rome: Associazione Bruno Trentin, pp. 27-39.

Royle A, Cavallini M, Gold M and Senatori I (2016) The effects of national institutional contexts and the recast directive on the European Works Council at UniCredit. European Journal of Industrial Relations 22(2): 115-130.

Rüb S (2002) World works councils and other forms of global employee representation in transnational undertakings: A survey. Düsseldorf: Hans-Böckler-Stiftung.

Rüb S, Platzer H and Müller T (2013) Transnational Company Bargaining and the Europeanization of Industrial Relations: Prospects for a Negotiated Order. Bern: Peter Lang.

Streeck W (1997) Neither European nor works councils: A reply to Paul Knutsen. Economic and Industrial Democracy 18(2): 325-337.

Telljohann V, da Costa I, Müller T, Rehfeldt U and Zimmer R (2009) European and international framework agreements: New tools of transnational industrial relations. Transfer: European Review of Labour and Research 15(3-4): 505-525. 
Waddington J (2011) European Works Councils and Industrial Relations: A Transnational Industrial Relations Institution in the Making. London: Routledge.

Whittall M, Martínez Lucio M, Mustchin S, Rocha F and Telljohann V (2015) The implementation of the Global Labour Relations Charter at Volkswagen. In: Leonardi S (ed.) Transnational Company Agreements: Experience and Prospects. Rome: Associazione Bruno Trentin, pp. 71-117.

\section{Author biographies}

Michael Whittall teaches Sociology of Work and Industrial Relations at the Friedrich-AlexanderUniversität Erlangen-Nürnberg, Germany and European Employment Relations at Nottingham Trent University, United Kingdom.

Miguel Martínez Lucio is a professor in Comparative Industrial Relations and International Human Resource Management (HRM) at the University of Manchester, United Kingdom.

Stephen Mustchin is a lecturer in Employment Studies, University of Manchester, United Kingdom.

Volker Telljohann is a senior researcher in Industrial Relations at Institute for Economic and Social Research (IRES) Emilia-Romagna, Bologna, Italy.

Fernando Rocha Sánchez is a director of Studies on Employment, Industrial Relations and Social Economy at Fundación $1^{\circ}$ de Mayo, Madrid, Spain 